\title{
Emergency service visits of fibromyalgia patients
}

\section{Fibromyalji hastalarının acil servis başvuruları}

Sadiye Yolcu' ${ }^{1}$ Özlem Balbaloğlu², N. Gökben Beceren ${ }^{3}$, Önder Tomruk ${ }^{3}$

\section{ABSTRACT}

Objective: We aimed to evaluate the emergency service admission frequencies of fibromyalgia patients with their sociodemographic properties.

Methods: A questionnaire form was applied to 136 fibromyalgia patients who admitted to our Physical Treatment and Rehabilitation Clinic and a control group of 132 nonfibromyalgia adult volunteers.

Results: Last emergency service admission complaints $(p<0.05)$, last emergency service admission time $(p<0.05)$, satisfaction of last emergency visits $(p<0.05)$ of the groups were significantly different but result of last emergency admissions ( $p>0.05$ ) were not different.

In the fibromyalgia group, status of working is negatively correlated with satisfaction of last emergency visit $(p<0.05, r=-0.170)$. Number of persons at home is positively correlated with frequency of emergency visit $(p<0.05, r=0.255)$, frequency of outpatient clinic admission $(p<0.05, r=-0,204)$ and result of last emergency admission $(p<0.05, r=0,224)$.

Conclusion: Detailed evaluation of fibromyalgia patients' symptoms and sociodemographic properties and appropriate treatment of these patients may be beneficial for decreasing their emergency service admission rates. $J$ Clin Exp Invest 2014; 5 (4): 539-543

Key words: Fibromyalgia, emergency service, sociodemographic properties

\section{INTRODUCTION}

It is known that $10 \%$ to $12 \%$ of the general population has chronic generalized musculoskeletal pain without a specific structural or inflammatory cause [1]. This idiopathic widespread pain most often fits the classification criteria for fibromyalgia syndrome (FMS) [2]. History of widespread pain, defined as bilateral, upper and lower body, as well as spine,

\section{ÖZET}

Amaç: Çalışmamızda, fibromiyalji hastalarını sosyodemografik özellikleri ile birlikte değerlendirerek acil servis başvuru sıklıklarını belirlemeyi amaçladık.

Yöntemler: Fizik tedavi ve rehabilitasyon polikliniğimize başvuran 136 fibromiyalji hastasına ve 132 kişilik fibromiyalji olmayan gönüllü kontrol grubuna anket formu uygulandı.

Bulgular: Gruplar arasında son acil servis başvuru şikayeti $(p<0,05)$, son acil servis başvuru zamanı $(p<0,05)$, son acil servis başvuru memnuniyeti $(p<0,05)$ anlamlı fark bulunurken, son acil servis başvurularındaki sonuçlanma şekilleri arasında fark yoktu ( $p>0,05)$. Fibromyalji grubunda çalışma durumu son acil servis başvuru memnuniyeti ile negatif olarak korele idi $(p<0,05, r=-0,170)$. Evde yaşayan kişi sayısı $(p<0,05, r=0,255)$, normal poliklinik başvuru sıklığı $(p<0,05, r=-0,204)$ ve son acil servis sonuçlanma şekli ( $p<0,05, r=0,224)$ ile acil servis başvuru sıklığı arasında pozitif korelasyon bulundu.

Sonuç: Fibromyalji hastalarının semptom ve sosyodemografik özelliklerinin ayrıntılı değerlendirilmesi ve uygun tedavi bu hastaların acil servis başvuru sıklıklarını azaltmada faydalı olabilir.

Anahtar kelimeler: Fibromiyalji, acil servis, sosyodemografik özellik

and the presence of excessive tenderness on applying pressure to 11 of 18 specific muscle-tendon sites are enough for a patient to be diagnosed with FMS [3]. FMS prevalence is $2 \%$ in the United States, including $3.4 \%$ of women and $0.5 \%$ of men $[4,5]$. Fibromyalgia is the second most common disorder after osteoarthritis observed by rheumatologists $[6,7]$. Psychosocial factors contribute greatly to the clinical expression of FMS and related dis-

${ }^{1}$ Bozok University Department of Emergency Medicine Yozgat, Turkey

${ }^{2}$ Bozok University Department of Physical Treatment and Rehabilitation Yozgat, Turkey

${ }^{3}$ Süleyman Demirel University Department of Emergency Medicine Isparta, Turkey

Correspondence: Sadiye Yolcu, Bozok University Department of Emergency Medicine Yozgat/Turkey Email: sadiyeyolcu@yahoo.com 
orders [8]. Kirmayer and colleagues studied in 20 FMS patients and 23 rheumatoid arthritis controls and found no significant difference in current or lifetime depression. While they did not conclude, as other investigators did, that fibromyalgia was a type of somatized depression, they did report that the fibromyalgia patients had more somatic symptoms of obscure origin, had more numerous somatic complaints, had endured more surgical procedures, and had sought medical help more frequently [9]. FMS results in profound suffering, including widespread musculoskeletal pain and stiffness, fatigue, disturbed sleep, dyscognition, affective distress, and very poor quality of life $[10,11]$.

This cross-sectional study aimed to investigate the reasons and the frequency of emergency visits of fibromyalgia patients. We also tried to evaluate the sociodemographic properties and comorbid psychopathologies of fibromyalgia patients to help emergency physicians for emergency intervention and treatment of these patients.

\section{METHODS}

After the Bozok University Ethics Council approval, questionnaire form was applied to 136 fibromyalgia patients who admitted to our Physical Treatment And Rehabilitation Clinic. And also, a control group of 132 non-fibromyalgia adult volunteers were included to the study. Control group was constituted of non-FMS volunteers. All participants were questionnaired for age, gender, working/nonworking, monthly income, how many people she/he is living with at home, having a chronical disease, usage of antidepressants, the last emergency service admission complaint/time, frequency of emergency admissions, frequency of admissions to an outpatient clinic, result of last emergency admission, satisfaction of the patient from the last emergency service doctor and the doctor's intervention. The questionnaire form was prepared by the researchers.

Statistical Package for Social Sciences (SPSS) for Windows 20.0 program was used for statistical analysis. Continuous variables were expressed as mean standard deviation (SD) and categorical variables were expressed as percentage. An analysis of normality of the continuous variables was performed with the Kolmogorov-Smirnov test. Differences in the means of continuous variables between groups (fibromyalgia-nonfibromyalgia) were analyzed using Kruskal-Wallis test. Continuous variables were also compared using an independent-groups ChiSquare test because normality assumptions were not met. Spearman correlation test was used for correlation analyses. A p-value of $<0.05$ was considered statistically significant.

\section{RESULTS}

We included 124 (91.2\%) females, 12 males (8.8\%) totally 136 fibromyalgia patients to our study. The control group was constituted of 105 (79.5\%) females, $27(20.5 \%)$ males totally 132 adult volunteers. Mean age of fibromyalgia patients was $42.00+/ \pm 8.934$. Mean age of the control group was $36.21 \pm 6.957$. We couldn't find a significant difference according to working status between groups $(p>0.05)$. But there were significant differences between groups with respect to monthly income $(p<0.05)$, count of persons living together at home $(p<0.05)$ (Table 1). History of chronic disease $(p<0.05)$, frequency of an outpatient clinic admission $(p<0.05)$, frequency of emergency service admissions $(p<0.05)$ of groups were significantly different (Table 2). Last emergency service admission complaints $(p<0.05)$, last emergency service admission time $(p<0.05)$, satisfaction of last emergency visits $(p<0.05)$ of the groups were significantly different but result of last emergency admissions $(p>0.05)$ were not different (Table 3).

In the FMS group, gender is positively correlated with status of working $(p<0.05, r=0.482)$, result of last emergency admission $(p<0.05, r=0.363)$ and negatively correlated with having chronic disease $(p<0.05, r=-.350)$. Status of working is positively correlated with monthly income $(p<0.05, r=$ 0.550 ) but negatively correlated with satisfaction of last emergency visit $(p<0.05, r=-0.170)$. Monthly income is positively correlated with last emergency admission complaint $(p<0.05, r=0.258)$. Number of persons at home is positively correlated with chronic disease $(p<0.05, r=0.192)$. Frequency of emergency visit $(p<0.05 . r=0.255)$. frequency of outpatient clinic admission $(p<0.05 . r=0-.204)$ and result of last emergency admission $(p<0.05 . r=0.224)$. Presence of chronic disease is positively correlated with last emergency admission complaint $(p<0.05 . r$ $=0.451$ ). Last emergency service admission complaint is correlated with satisfaction $(p<0.05, r=$ -.170). Frequency of emergency service admission and frequency of outpatient clinic admission are positively correlated $(p<0.05 . r=0.465)$. Frequency of emergency service admission and last emergency service admission time are positively correlated $(p<0.05, r=0.680)$. Frequency of outpatient clinic admission and last emergency service admission 
time are positively correlated $(p<0.05, r=0.471)$. Result of last emergency admission is positively correlated with satisfaction of last emergency ser- vice visit $(p<0.05, r=-0.173)$. Satisfaction of last emergency service visit is negatively correlated with last emergency admission time $(p<0.05, r=-0.199)$.
Table 1. Job status, monthly income, count of persons living together at home of the groups

\begin{tabular}{lcccc}
\hline & & $\begin{array}{c}\text { FMS Group } \\
\mathrm{n}(\%)\end{array}$ & $\begin{array}{c}\text { Controls } \\
\mathrm{n}(\%)\end{array}$ & $\mathrm{p}$ \\
\hline \multirow{3}{*}{ Job status } & Nonworking & $96(70.6)$ & $88(66.7)$ & \\
& Working & $40(29.4)$ & $44(33.3)$ & 0.489 \\
& Total & $136(100)$ & $132(100)$ & \\
& Under 1000 TL & $64(47.1)$ & $63(47.7)$ & \\
Monthly income & $1000-2000 \mathrm{TL}$ & $52(38.2)$ & $51(38.6)$ & \\
& $2000-5000 \mathrm{TL}$ & $20(14.7)$ & $12(9.1)$ & 0.047 \\
& $5000-10000 \mathrm{TL}$ & $0(0)$ & $6(4.5)$ & \\
& Total & $136(100)$ & $132(100)$ & \\
Count of persons & 1 & $4(2.9)$ & $22(16.7)$ & \\
home & 2 & $24(17.6)$ & $39(29.5)$ & \\
& 3 & $36(26.5)$ & $29(22.0)$ & $<0.001$ \\
& $>3$ & $72(52.9)$ & $42(31.8)$ & \\
& Total & $136(100)$ & $132(100)$ & \\
\hline
\end{tabular}

TL: Turkish Liras, FMS: Fibromyalgia syndrome
Table 2. Chronic disease, antidepressant usage, frequency of an outpatient clinic admission, frequency of emergency service admissions of groups

\begin{tabular}{|c|c|c|c|c|}
\hline & & $\begin{array}{c}\text { FMS Group } \\
\text { n (\%) }\end{array}$ & $\begin{array}{c}\text { Controls } \\
n(\%)\end{array}$ & $\mathrm{p}$ \\
\hline \multirow{3}{*}{ Chronical Disease } & $(+)$ & $60(44.1)$ & $29(22)$ & \multirow{3}{*}{$<0.001$} \\
\hline & $(-)$ & $76(55.9)$ & $103(78)$ & \\
\hline & Total & $136(100)$ & $132(100)$ & \\
\hline \multirow{3}{*}{ Antidepressant usage } & $(+)$ & $44(32.4)$ & $29(22)$ & \multirow{3}{*}{0.056} \\
\hline & $(-)$ & $92(67.6)$ & $103(78)$ & \\
\hline & Total & $136(100)$ & $132(100)$ & \\
\hline \multirow{7}{*}{$\begin{array}{l}\text { Frequency of an out- } \\
\text { patient clinic admis- } \\
\text { sion }\end{array}$} & Once a week & $4(2.9)$ & $0(0)$ & \multirow{7}{*}{$<0.001$} \\
\hline & Once a month & $40(29.4)$ & $5(3.8)$ & \\
\hline & Once per 3 months & $60(44.1)$ & $12(9.1)$ & \\
\hline & Once per 6 months & $20(14.7)$ & $29(22.0)$ & \\
\hline & Once per year & $8(5.9)$ & $59(44.7)$ & \\
\hline & Once per more than 1 year & $4(2.9)$ & $27(20.5)$ & \\
\hline & Total & $136(100)$ & $132(100)$ & \\
\hline \multirow{6}{*}{$\begin{array}{l}\text { Frequency of emer- } \\
\text { gency service admis- } \\
\text { sion }\end{array}$} & Once a month & $12(8.8)$ & $0(0)$ & \multirow{6}{*}{$<0.001$} \\
\hline & Once per 3 months & $52(38.2)$ & $0(0)$ & \\
\hline & Once per 6 months & $28(20.6)$ & $12(9.1)$ & \\
\hline & Once per year & $32(23.5)$ & $41(31.1)$ & \\
\hline & Once per more than 1 year & $12(8.8)$ & $79(59.8)$ & \\
\hline & Total & $136(100)$ & $132(100)$ & \\
\hline
\end{tabular}

FMS: Fibromyalgia Syndrome 
Table 3. Last emergency service admission complaint, last emergency service admission time, result of last emergency admission, satisfaction of last emergency visits of the groups

\begin{tabular}{|c|c|c|c|c|}
\hline & & $\begin{array}{c}\text { FMS Group } \\
\mathrm{n}(\%)\end{array}$ & $\begin{array}{l}\text { Controls } \\
\mathrm{n}(\%)\end{array}$ & $\mathrm{p}$ \\
\hline \multirow{6}{*}{$\begin{array}{l}\text { Last ES admission } \\
\text { complaint }\end{array}$} & Musculoskeletal pain & $52(38.2)$ & $17(12.9)$ & \multirow{7}{*}{$<0.001$} \\
\hline & Neurological symptoms & $28(20.6)$ & $35(26.5)$ & \\
\hline & GIS symptoms & $8(5.9)$ & $35(26.5)$ & \\
\hline & Anxiety & $24(17.6)$ & $0(0)$ & \\
\hline & Trauma & $8(5.9)$ & $6(4.5)$ & \\
\hline & Other & $16(11.8)$ & $39(29.5)$ & \\
\hline \multirow{8}{*}{$\begin{array}{l}\text { Last ES admission } \\
\text { time }\end{array}$} & Total & $136(100)$ & $132(100)$ & \\
\hline & Within 1 week & $4(2.9)$ & $0(0)$ & \multirow{7}{*}{$<0.001$} \\
\hline & Within 1 month & $12(8.8)$ & $12(9.1)$ & \\
\hline & Within 3 month & $60(44.1)$ & $28(21.2)$ & \\
\hline & Within 6 month & $16(11.8)$ & $0(0)$ & \\
\hline & Within 1 year & $24(17.6)$ & $34(25.8)$ & \\
\hline & More than 1 year & $20(14.7)$ & $58(43.9)$ & \\
\hline & Total & $136(100)$ & $132(100)$ & \\
\hline \multirow{3}{*}{$\begin{array}{l}\text { Result of last ES ad- } \\
\text { mission }\end{array}$} & Discharged & $128(94.1)$ & $126(95.5)$ & \multirow{3}{*}{0.623} \\
\hline & Hospitalized & $8(5.9)$ & $6(4.5)$ & \\
\hline & Total & $136(100)$ & $132(100)$ & \\
\hline \multirow{3}{*}{$\begin{array}{l}\text { Satisfaction of last } \\
\text { emergency visit }\end{array}$} & Yes & $92(67.6)$ & $120(90.9)$ & \multirow{3}{*}{$<0.001$} \\
\hline & No & $44(32.4)$ & $12(9.1)$ & \\
\hline & Total & $136(100)$ & $132(100)$ & \\
\hline
\end{tabular}

FMS: Fibromyalgia Syndrome, GIS: Gastrointestinal symptoms, ES: Emergency service

\section{DISCUSSION}

Chronic pain is a common reason for presentation to the emergency department (ED) and emergency physicians deal with acute pain generously, using the wide range of therapeutic options at their disposal $[12,13]$.

Baker et al reported that emergency physicians need to differentiate chronic pain breakthroughs from acute intermittent pain and should recognize those at risk of chronic pain, forestall the syndrome's beginnings, and rationally exclude intercurrent illness. They suggested that a better understanding of chronic pain, and knowledge of current management practices may reduce clinician angst, lead to more consistent, less prejudicial interventions for patients presenting with chronic pain syndromes to emergency departments [14].
Fibromyalgia patients often represent themselves to emergency services for pain management and not for diagnosis [15]. Lack of literature of these patients' emergency admissions causes emergency physicians intervention to these patients.

Our FMS group was constituted of $124(91.2 \%)$ females, 12 males $(8.8 \%)$ as known in literature $[4,5]$. All males had a job and most of the females were not working and they were all housewives. Similar to Kirmayer's study [9] frequency of an outpatient clinic admission and frequency of emergency service admissions of groups were significantly different. Last emergency service admission complaints, last emergency service admission time, satisfaction of last emergency visits of the groups were different. Fibromyalgia patients visited a doctor and emergency service much more than other group. 
Number of persons at home is positively correlated with frequency of emergency visit and frequency of outpatient clinic admission. These results showed that sociodemographic status has an effect on hospital admissions.

Frequency of emergency service admission and frequency of outpatient clinic admission were positively correlated. Satisfaction of last emergency visit ratio was lower in FMS group. This made us think the FMS patients found the doctor's evaluation insufficient or they think that they are not being taken seriously. Ducharme and McLoad reported that physicians may feel

a sense of anger and helplessness when confronted with chronic unexplained pain $[13,16]$.

Most of our FMS group (38.2\%) last emergency admission complaint was musculoskeletal complaint. In a retrospective study, Davidson et al studied in 204 FMS patients who admitted to emergency department with musculoskeletal pain. They investigated the rate of occurrence of fibromyalgia among patients assessed for pain management in a community hospital ED. During 21 -month period, $5 \%$ of musculoskeletal pain patients had been diagnosed with fibromyalgia. In their study of the 204 patients, 22 had musculoskeletal chest pain for which cardiac pathology was ruled out. Thirteen patients presented with myositis as a result of a motor vehicular accident or a slip-and-fall accident; 40 patients had musculoskeletal pains or myositis [15].

Most of patients in the study group were nonworking people, and this situation makes more difficult to discuss the effect of having a job and active working on fibromyalgia.

In conclusion, sociodemographic properties of fibromyalgia patients play an important role in FMS patients' emergency service admissions and their satisfaction. Detailed evaluation of fibromyalgia patients' symptoms and sociodemographic properties and appropriate treatment of these patients may be beneficial for decreasing their emergency service admission rates.

Conflict of Interest: All authors declare that they have no conflict of interest.

\section{REFERENCES}

1. Croft P, Rigby AS, Boswell R, et al. The prevalence of chronic widespread pain in the general population. $\mathrm{J}$ Rheumatol 1993;20:710-713.
2. Croft P, Schollum J, Silman A. Population study of tender point counts and pain as evidence of fibromyalgia. BMJ 1994;309:696-699.

3. Wolfe F, Smythe HA, Yunus MB, et al. The American College of Rheumatology 1990 criteria for the classification of fibromyalgia: report of the Multicenter Criteria Committee. Arthritis Rheum 1990;33:160-172.

4. Wolfe F, Cathey MA. Prevalence of primary and secondary fibrositis. J Rheumatol 1983;10:965-968.

5. Wolfe F, Cathey MA. The epidemiology of tender points. J Rheumatol 1985;12:1164-1168.

6. Marder WD, Meenan RF, Felson DT, et al. Editorial: the present and future adequacy of rheumatology manpower: a study of health care needs and physician supply. Arthritis Rheum 1991;34:1209-1217.

7. Crofford LJ, Clauw DJ. Fibromyalgia: where are we a decade after the American College of Rheumatology classification criteria were developed? Arthritis Rheum 2002;46:1136-1138.

8. Benjamin S, Morris S, Mcbeth J, et al. The association between chronic widespread pain and mental disorder. Arthritis Rheum. 2000;43:561-567.

9. Kirmayer LJ, Robbins JM, Kapusta MA. Somatization and depression in fibromyalgia syndrome. Am J Psychiatry 1988;8:950-954.

10. Burckhardt CS, Bjelle A. Perceived control: A comparison of women with fibromyalgia, rheumatoid arthritis, and systematic lupus erythematosus using a Swedish version of the rheumatology attitudes index. Scand $\mathrm{J}$ Rheumatol 1996;25:300-306.

11. Ledingham J, Doherty S, Doherty M. Primary fibromyalgia syndrome - an outcome study. $\mathrm{Br} \mathrm{J}$ Rheumatol 1993;32:139-142.

12. Cordell W, Keene K, Giles B, et al. The high prevalence of pain in emergency medical care. Am J Emerg Med 2002;20:165-169.

13. Ducharme J. Acute pain and pain control: state of the art. Ann Emerg Med 2000;35:592-603.

14. Baker K. Chronic pain syndromes in the emergency department: Identifying guidelines for management. Emergency Medicine Australasia 2005;17:57-64.

15. Davidson PW. Fibromyalgia and Psychopathology in a Community Hospital Emergency Room. Primary Psychiatry 2003;10:69-73.

16. MacLeod DB, Swanson R. A new approach to chronic pain in the emergency department. Am J Emerg Med1996;14:323-326. 